\title{
A History of Higher and Professional Correspondence Education in the UK
}

\author{
Stephen A. Hunt
}

\begin{abstract}
Correspondence education, or learning by post, lasted over 100 years in the UK, it had its roots in the 19th century, peaking in the mid-1960s. It was also widespread, numbering hundreds of thousands of enrolments, significantly increasing access to higher education. Yet it has been marginalised in accounts of British higher education. This is partly because it was largely private and for-profit and so distinct from the public education system, while the state declined to play any significant role in its oversight. Consequently, little official data concerning correspondence education has ever been available.
\end{abstract}

This paper constructs an account of the history of correspondence education in the UK in terms of its development as a form of academic and professional provision, and its regulatory framework. The paper also considers the reasons for the eventual demise of the correspondence education sector following changes in teaching methods, and the impact of digital technology.

Keywords: Correspondence education, private higher education, learning by post, UK.

\section{Introduction}

Correspondence education is fleetingly referred to, if not entirely absent from standard accounts of UK higher education. Yet, at its peak estimates of enrolments were around half to three-quarters of a million. Indicative of such mass-participation, correspondence education acted as an important means of widening participation in higher education; for decades it provided one of the only ways of studying for a degree without attending university. It also provided an accessible method of study for a wide variety of professional and vocational qualifications; in some cases, such as chartered accountancy, it was the only form of tuition available. Few correspondence education providers existed in the public sector, most operated as private for-profit enterprises, subject to little regulation.

Correspondence education stands as the most significant form of private tertiary education the UK has yet seen, yet it has seldom been written about. ${ }^{1}$ International research concerning correspondence education has also been sparse and intermittent, only condensing into an active academic area from the 1960 s onwards. ${ }^{2}$

This paper attempts to trace the history of correspondence education in the UK in terms of its development as a form of higher education provision, and as a principal source of tuition for professional qualifications. It examines the characteristics and motives of its students, along with the character and attitudes of correspondence tutors. The paper also traces developments in what regulation the sector was eventually subject to, and the forces, such as an increase in demand for face-to-face tuition and technological innovation, that acted to eliminate much and transform what remained of the correspondence education sector.

\footnotetext{
${ }^{1}$ Robert Bell and Malcolm Tight, Open Universities: A British Tradition? (Milton Keynes: Open University Press, 1993); W. J. A. Harris, The Distance Tutor. Education by Correspondence, Manchester Monographs (Manchester: Manchester University Adult Education, 1975).

2 Borje Holmberg, 'The Development of Distance Education Research', American Journal of Distance Education 1, no. 3 (1987): 16-23.
} 
Correspondence education at its zenith became the largest form of adult education in the UK, with an estimated half million enrolments in the mid-1960s. ${ }^{3}$ Despite its scale, the position of correspondence education in the educational sector has always been marginal, and, as Keegan puts it, 'Hostility from the education establishment was rarely far from the surface'. ${ }^{4}$ The Carr-Saunders Committee of 1949, considering education for the commercial professions, was largely opposed to study through correspondence education alone. It was felt, given the nature of the courses that without face-to-face tuition and the opportunity for discussion, few students, particularly younger students, would be capable of benefiting from correspondence tuition alone. Underlying this was a sense that the aim of course enrolment should not be entirely reduced to passing an exam. ${ }^{5}$

The Crowther Committee, 1959, concerned with education of 15 - 18 year olds, mentioned correspondence education as being arduous in nature, and leaving scant opportunity for the free and spontaneous interplay of mind on mind. The McMeeking Committee, 1959, concerned with education for commerce, recommended that colleges of commerce should offer intensive courses to correspondence students 'to offset the obvious disadvantages inherent in isolated study'. ${ }^{6}$ Young and Farrell ${ }^{7}$ characterised the attitude of people in ordinary education towards the correspondence method as 'contemptuous'.

If the hostility was infrequently expressed, this was simply because correspondence education was so rarely considered: the educational establishment, and the state generally, largely ignored correspondence education.

The lack of attention can be partly explained by the fact that correspondence education was largely conducted by private often for-profit enterprises, which meant an element of higher education fell within the private sector, and its development was entirely separate from state funded education. ${ }^{8}$ Consequently, it went unmonitored: the data that existed was collected by private institutions and had commercial value; little entered the public sphere. The lack of data is something remarked on by successive researchers in the field. Young and Farrell, researching the users of correspondence colleges in the journal Where? wrote '...more facts are needed. Hence this small investigation. The colleges did not prove receptive to the enquiry, but such is the absence of information the results are worth reporting all the same'. 9 Similarly, the consumer magazine Which? (1963) stated 'Nobody knows just how many people are taking courses from British correspondence schools.... ${ }^{10}$ Years later Glatter et al.. ${ }^{11}$ found the situation unchanged: 'Statistical evidence of growth in correspondence

\footnotetext{
${ }^{3}$ Ronald Glatter et al., Study by Correspondence; An Enquiry Into Correspondence Study for Examinations for Degrees and Other Advanced Qualifications (London: Longman, 1971), http://eric.ed.gov/?id=ED031637.

${ }^{4}$ Desmond Keegan, Foundations of Distance Education, Third (London: Routledge, 1996), 4.

${ }^{5}$ Evan Finlay, 'Education for the Commercial Professions', The Vocational Aspect of Education 6, no. 13 (1 September 1954): 120-23, https://doi.org/10.1080/03057875480000121; W. J. A. Harris, 'Education by Post (England)', in The Changing World of Correspondence Education: International Readings, ed. Ossian Mackenzie and Edward Christensen L. (University Park \& London: The Pennsylvania State University Press, 1971), 299-302.

${ }^{6}$ Glatter et al., Study by Correspondence; An Enquiry Into Correspondence Study for Examinations for Degrees and Other Advanced Qualifications, 25.

${ }^{7}$ Michael Young and Christine Farrell, 'Who Uses Correspondence Colleges?', Where?, no. Autumn (1963): 12.

${ }^{8}$ Gareth L. Williams and Maureen Woodhall, Independent Further Education, vol. 45, 581 (Policy

Studies Institute, 1979).

${ }^{9}$ Young and Farrell, 'Who Uses Correspondence Colleges?', 12.

${ }^{10}$ Which?, 'Correspondence Courses', Which?, no. October (1963): 305-12.

11 Glatter et al., Study by Correspondence; An Enquiry Into Correspondence Study for Examinations for Degrees and Other Advanced Qualifications, 5.
} 
education is...limited and unsystematic'. Elliott ${ }^{12}$ writing about correspondence education 1848 - 1914 stated 'It has not been possible, except within certain limits, to quantify provision of postal tuition'. Where Elliott was able to cite figures these were frequently drawn from adverts placed by commercial correspondence schools themselves. This work attempts to bring together what research is available and to plot the key features of correspondence education in the UK.

\section{The emergence of correspondence education in the UK}

The Robbins report ${ }^{13}$ appeared in 1963 and, although the fifth educational report since February 1959, it was effectively the point at which correspondence education was specifically identified as an element of the British higher education system, estimating it was being undertaken by at least 60,000 individuals studying for commercial and legal professional qualifications alone. ${ }^{14}$ Correspondence education was though, by the time of the Robbins report, well over a century old.

Something of a precursor to a correspondence school, the philanthropic Society for the Diffusion of Useful Knowledge (1826 - 1848) promoted self-education, as opposed to engaging in any teaching, through the distribution of low-cost educational publications. ${ }^{15}$ The first known advert for correspondence based education involving two-way interaction dates from $1833,{ }^{16}$ although Pitman's shorthand course established in 1844 is generally credited with being the first correspondence course its defining features being the provision of materials or direct teaching, and timely feedback on students' submitted work. ${ }^{17}$ However, it was not until the latter part of the 19th century that significant private correspondence schools in Britain were established. Capitalising on the development of a postal service and railway infrastructure they were a commercial response to the development of professional organisations, the emergence of membership by examination, and the scarcity of educational facilities. ${ }^{18}$ Skerry's in Edinburgh was founded in 1878, concentrating on tuition for civil service exams; University Correspondence College (UCC), Cambridge, founded in 1887; H. Foulks Lynch and Co in 1884 concentrating on accountancy; Chambers in 1885, and the Diploma Correspondence College/ Wolsey Hall College, Oxford, in 1894. Subsequently, a multiplicity of correspondence colleges were established, including the Bennett college, in Sheffield ${ }^{19}$ in 1900, the International Correspondence School in 1901, a

\footnotetext{
${ }^{12}$ Stanley Elliott, 'Tuition by Correspondence: A Study of Growth in Britain, Principally during the Period 1870 to 1914' (Masters, University of Leicester, 1973), viii.

${ }^{13}$ Committee on Higher Education, 'Report of the Committee on Higher Education (the Robbins Report)' (London: HMSO, 1963).

${ }^{14}$ Committee on Higher Education, Appendix Two (B), Table BB.5, 540.

15 Joel Mokyr, The Enlightened Economy: An Economic History of Britain, 1700-1850, New Economic History of Britain (New Haven ; London: Yale University Press, 2009).

${ }^{16}$ D. R. Garrison, 'Three Generations of Technological Innovations in Distance Education', Distance Education 6, no. 2 (1 September 1985): 235-41, https://doi.org/10.1080/0158791850060208.

${ }^{17}$ Alan Tait, 'Reflections on Student Support in Open and Distance Learning', The International Review of Research in Open and Distributed Learning 4, no. 1 (2003).

${ }^{18}$ Glatter et al., Study by Correspondence; An Enquiry Into Correspondence Study for Examinations for Degrees and Other Advanced Qualifications.
}

\footnotetext{
${ }^{19}$ Anthony Burgess, '1985', in Future Imperfect (London: Vintage, 1994), 299-300. Anthony Burgess claims that George Orwell's inspiration for his Big Brother character was partly derived from a Bennett's advert: when Bennett senior was replaced by his son - 'a very brutal-looking individual' - the slogan in Bennett's' adverts changed from 'Let me be your father' to 'Let me be your big brother'. However, no examples of the later adverts have yet been found; Ray Girvan, 'Predictions', JSBlog Journal of a Southern Bookreader (blog), 2008, http://jsbookreader.blogspot.com/2008/03/predictions.html.
} 
US off-shoot specialising in engineering courses, the Metropolitan College in London in 1910, and Rapid Results College in 1928.

Eventually the sector became dominated by nine large private colleges, mainly concentrating on commercial subjects; two were concerned with technical subjects, and two with university degrees. ${ }^{20}$

Before the arrival of the Open University in 1969 a University qualification taught by correspondence was likely to have been from the University of London.

Until 1900 the University of London existed only to 'define syllabuses, conduct examinations and award degrees', ${ }^{21}$ 'teaching responsibilities remaining the concern of the multitude of colleges, institutes and schools that sheltered under the federal umbrella'. ${ }^{22}$ The University established a parallel system: institutions belonging to the University taught Internal qualifications, those outside could, if recognised, teach External qualifications: the qualifications ranged from the entry level matriculation to masters.

A Royal Charter of 1858 allowed the University of London to enrol students to sit its exams (excluding medicine) irrespective of where, or how they had studied: privately, at affiliated or recognised institutions, or by correspondence. The requirement of a certificate of study from a recognised institution was dropped. The only restrictions were the registration fee ( $£ 5.00$ for each the BA's two stages) and gender: women were only granted access to certificates and diplomas in 1867, and full degrees in $1878 .^{23}$

The private sector quickly took advantage of the opportunity provided by the University of London. The University Correspondence College (UCC) - an educational trust - offered tuition in every University of London examination, from matriculation to the MA. With an initial faculty of 20 - at one point counting H.G Wells amongst its number who had also passed a London BSc in zoology - it became increasingly significant: in 189040 per cent of Arts graduates had studied with UCC, by 1899 the figure was 60 per cent. ${ }^{24}$ Wolsey Hall also offered correspondence tuition for all University of London exams; Rapid Results College tuition in some. There was a clear impact of correspondence colleges on attainment:

...in 186570.5 per cent of those who registered as 'private' students failed to pass. By the end of the century, thanks largely to the efforts of the correspondence colleges, the situation had reversed with more success among the non-collegiate than the collegiate students. ${ }^{25}$

\footnotetext{
${ }^{20}$ Glatter et al., Study by Correspondence; An Enquiry Into Correspondence Study for Examinations for Degrees and Other Advanced Qualifications; Geoffrey Millerson, The Qualifying Associations: A Study in Professionalization (London: Routledge and Kegan Paul, 1964).

${ }^{21}$ Richard Arnold, 'Models of Student Support within the University of London External System: Historical Development and Future Evolution', European Journal of Open, Distance and E-Learning 7 , no. 2 (11 August 2004), http://www.eurodl.org/?p=archives\&year=2004\&halfyear=\&article=125.

22 Malcolm Tight, 'London University External Developments', Open Learning: The Journal of Open, Distance and e-Learning 2, no. 2 (1 June 1987): 49-51, https://doi.org/10.1080/0268051870020214.

${ }^{23}$ Christine Kenyon-Jones, The People's University 1858-2008: 150 Years of the University of London and Its External Students (University of London, 2008),

https://kclpure.kcl.ac.uk/portal/en/publications/the-peoples-university-18582008-150-years-of-theuniversity-of-london-and-its-external-students(54319612-7d80-4355-b5a6-9ff988c75386).html. ${ }^{24}$ Stanley Elliott, 'Tuition by Post: An Historical Perspective', Teaching at a Distance 11 (1978): 12 16.

${ }^{25}$ Kenyon-Jones, The People's University 1858-2008, 23.
} 
More specifically, between 1887-1931 39,326 students passed exams through the UCC, 10,000 of which graduated with Bachelor or Masters degrees ${ }^{26}$ Other educational ventures included those undertaken by the Co-operative Union. Independent of the state, an education committee was established in 1885 and courses subsequently offered in economics, citizenship, industrial history, and the history and principles of co-operation. Along with other forms of delivery correspondence courses were introduced from $1890 .{ }^{27}$

Commercial correspondence colleges were not just wedged into the higher education system through enterprising zeal: on occasion they were directly co-opted by the state. Wolsey Hall and Metropolitan, amongst others, provided tuition from secondary school to (University of London accredited) degree level to servicemen in arrangement with the Institute of Army Education during World War II. ${ }^{28}$

There was some public sector involvement in correspondence education in the UK. St Andrews University's introduced its own distance learning programme in 1887 that effectively widened participation, even if it did not eradicate inequality. Barred from entering the Scottish Universities until 1892, women, were able to study for a singular qualification, in Scotland at local colleges, or internationally by correspondence: the Licentiate in Arts (LA), latterly the Lady Literate in Arts (LLA), held to be the equivalent of an MA. Over the course of its existence some 36,017 examinations had been entered, and the LLA awarded to 5,117 women. ${ }^{29}$ The Commerce Degree Bureau of the University of London, co-founded with the help of 'City business types' in the wake of the First World War, offered basic tuition in economics via correspondence, although face-to-face tuition was also provided. ${ }^{30}$ Ruskin College also offered a similar combination. ${ }^{31}$

The External degrees taught by correspondence maintained a slender but palpable presence in the face of expanding higher education provision: by 1966 there were 6,000 enrolments, amounting to less than three per cent of all students taking first degree courses; in the same year there were 70,000 enrolments for the General Certificate of Education by correspondence. ${ }^{32}$ The proportion of first degrees awarded to UK resident correspondence and private study students in 1966 was 1.1 per cent: 382 from a total of $36,146 .{ }^{33}$ External degrees faded from UK higher education, but were rebranded as International programmes, principally available overseas, currently they have over 50,000 enrolments in 180 countries. $^{34}$

\section{Correspondence education and the professions}

\footnotetext{
${ }^{26}$ Anna De Salvo, 'The Rise and Fall of the University Correspondence College: Pioneer of Distance Learning' (Cambridge: National Extension College, 2002).

${ }^{27}$ Tom Woodin, 'Co-Operative Education in Britain during the Nineteenth and Early Twentieth Centuries: Context, Identity and Learning', in The Hidden Alternative: Co-Operative Values, Past, Present and Future, ed. Anthony Webster, Linda Shaw, and Rachael Vorberg-Rugh (Manchester University Press, 2016), 87, https://read.un-ilibrary.org/economic-and-social-development/the-hiddenalternative_5dcd8d23-en.

${ }^{28}$ Ivor Morrish, Education Since 1800, 1st ed. (London: George Allen and Unwin, 1970).

${ }^{29}$ R.N. Smart, 'Literate Ladies - a Fifty Year Experiment', in St. Andrews University Alumni Chronicle, vol. 59, 1968, 21-31.

30 Tight, 'London University External Developments'.

31 Young and Farrell, 'Who Uses Correspondence Colleges?'

${ }^{32}$ Lyndon H Jones, 'Directed Private Study', The Vocational Aspect of Education XXI, no. 50 (1969): 107-11.

${ }^{33}$ Glatter et al., Study by Correspondence; An Enquiry Into Correspondence Study for Examinations for Degrees and Other Advanced Qualifications.

${ }^{34}$ University of London, 'About Us', University of London, 2019, https://london.ac.uk/about-us.
} 
De Salvo ${ }^{35}$ identifies the demand for correspondence degrees as largely stemming from the teaching profession - over 80 per cent of enrolments in the University Correspondence College were from teachers - where the value of a university degree was keenly felt. A university degree was advantageous, even critical, to a teacher's career prospects; without one they were likely to remain a 'pupil' or assistant teacher. Studying for a correspondence degree meant teachers could continue in employment while working towards a qualification that could double their income. Furthermore, prior to 1926 there was no requirement for those taking the government's teacher's certificate to actually attend any college.

Correspondence education also expanded with the emergence of open competition for Civil Service appointments in 1870, and as membership of professional bodies became exam based. ${ }^{36}$

...by the 1880s examinations had to be passed in order to become a barrister, solicitor, doctor, surgeon, clergyman, pharmacist, a merchant navy officer on a foreign-going ship, or a mine manager...Examinations had become accepted as an essential basis of the professions. ${ }^{37}$

The professions - as taught subjects - seldom had any presence in the university sector, nor was the professional bodies' pursuit of exam-based membership matched by provision of an educational infrastructure: tutors, textbooks and teaching institutions were all scarce. The demand for tuition was largely met by private correspondence colleges.

The Library Association, the Institute of Actuaries, the Chartered Insurance Institute, the Chartered Institute of Secretaries, the Institute of Chartered Accountants all became involved with correspondence education directed at their own professional exams during the first half of the $20^{\text {th }}$ century. Even in cases where there was no official involvement, students still made recourse to corresponded education. Before the Chartered Insurance Institute formally began correspondence courses, 90 per cent of its students were studying by correspondence. After the Chartered Institute of Secretaries abandoned correspondence tuition, the majority of its students continued to use it as a method of study. ${ }^{38}$

The private College of Estate Management (Kensington) was in a position to offer University of London internal degrees from 1938, as it was located within the University of London's catchment area and had recognised teachers. It provided both postal and face-to-face tuition (a style of education termed 'Soviet' by Young and Farrell where such a combination was standard) in the 'professions of the land'. The period 1962/3 had seen enrolments of $3,500-4,000$ students. $^{39}$

Millerson ${ }^{40}$ estimated that, in the mid-1960s, 50 to 90 per cent of degree candidates were using correspondence as a means of studying for exams for associations connected with commercial and business subjects.

At approximately the same time the Robbins report ${ }^{41}$ examined the provision of professional education via correspondence. The Robbins report found a high proportion - 91 per cent

\footnotetext{
${ }^{35}$ De Salvo, 'The Rise and Fall of the University Correspondence College: Pioneer of Distance Learning'.

${ }^{36}$ Elliott, 'Tuition by Post: An Historical Perspective'.

${ }^{37}$ Millerson, The Qualifying Associations, 25.

${ }^{38}$ Millerson.

39 Young and Farrell, 'Who Uses Correspondence Colleges?'

${ }^{40}$ Millerson, The Qualifying Associations.

${ }^{41}$ Committee on Higher Education, 'Report of the Committee on Higher Education (the Robbins Report)'.
} 
$(58,000)$ - of correspondence-only students were studying commercially orientated subjects, these included: banking; company secretaryship; insurance; and accountancy in particular the report found a third of all correspondence only students were studying accountancy. At a more specific level but at approximately the same point in time Young and Farrell ${ }^{42}$ identified use of correspondence education by professional societies, see Table 1.

Table 1: Proportion Studying by Correspondence for Professional Exams. Source: Michael Young and Christine Farrell, 'Who Uses Correspondence Colleges?', Where?, Autumn (1963): 12-14, 12.

\begin{tabular}{lll}
\hline Professional Society & Examination & $\begin{array}{l}\text { Percentage studied via } \\
\text { correspondence }\end{array}$ \\
\hline Institute of Chartered Accountants & Intermediate & $100 \%$ \\
& Finals & $100 \%$ \\
Institute of Costs and Works & Unspecified & $40 \%$ \\
Accountants & & \\
Law Society & Intermediate & $40 \%$ \\
& Finals & $35 \%$ \\
Chartered Institute of Secretaries & Unspecified & $50+$ \\
Institute of Chartered Surveyors & Unspecified & "rather less than half" \\
\hline
\end{tabular}

The high prevalence of accountancy students, and chartered accountancy students in particular, studying via correspondence identified by both Robbins and Young and Farrell is the direct result of a policy decision taken by the Institute of Chartered Accountants England and Wales. Determinedly opposed to public sector provision, the Institute insisted all tuition be conducted via correspondence ${ }^{43}$, and in practice this was delivered by a single provider: Foulks Lynch. This situation allowed the Institute maximum control over their curriculum, and hence the shape of their profession. The insistence on correspondence tuition was progressivity diluted throughout the 1960s, following recommendations in a 1961 report. Taking advantage of this relaxation, seven major accountancy colleges were established between 1965 and 1976 to teach accountancy face-to-face. ${ }^{44}$ The last of these, founded in 1976 as Brierley, Price, Prior \& Co eventually evolved into one of the UK's few private universities: BPP University. Accountancy by correspondence proved resilient, even though students preferred face-to-face tuition. Berridge ${ }^{45}$ in a survey of the British accountancy profession, found that by 197270 per cent of all students were still enrolled on correspondence courses, although in many cases this was augmented with face-to-face tuition.

Besides those compelled to study by correspondence, the characteristics and motives of students undertaking correspondence education remained for decades something of an unknown quantity; innumerable figures toiling away in obscurity.

\footnotetext{
42 Young and Farrell, 'Who Uses Correspondence Colleges?'

${ }^{43}$ Committee on Higher Education, 'Report of the Committee on Higher Education (the Robbins Report)' found evidence that some chartered accountancy students managed to supplement correspondence education with alternative forms of tuition - 12 per cent of the 250 sampled studying for Intermediate exam, and 17 per cent of 272 studying for the Final. Three per cent studying for the Final avoided using correspondence altogether.

${ }^{44}$ S.Belinda Geddes, 'The Development of Accountancy Education, Training and Research in England: A Study of the Relationship between Professional Education and Training, Academic Education and Research and Professional Practice in English Chartered Accountancy' (PhD, Department of Accounting and Finance; Faculty of Economics and Social Studies: University of Manchester, 1995), http://ethos.bl.uk/DownloadOrder.do?orderNumber=THESIS01349585.

45 T.M. Berridge, 'Survey of the British Accountancy Profession' (Advisory Board of Accountancy Education., 1975).
} 
The following sections examine what kind of individual studied via correspondence, their experiences and the likely outcomes, along with the attitudes and employment conditions of correspondence tutors.

\section{The characteristics and motives of correspondence education students}

Young and Farrell ${ }^{46}$ identified several reasons people had for studying by correspondence: flexibility of study; unavailability or inaccessibility of regular classes; unease in regular classes ('embarrassment'), and having the goal of passing written exams. Millerson ${ }^{47}$ summarised its disadvantages: student isolation; the greater demand for perseverance and will power; absence of comparative standards of judgement; uneven course standards.

Further research concerning British correspondence students was commissioned by the Department of Education and Science in 1966 resulting in Glatter et al.,'s Study in Correspondence ${ }^{48}$. This research involved a survey with an eventual sample of 12,077 students from the 1967 intake at 13 correspondence colleges. There was also a retrospective survey, administered through the exam boards, of approximately 2,000 students enrolled since 1963. The authors cite the figure of 284,000 enrolments in correspondence course annually, and a total figure for enrolments of about half a million.

The findings indicated a marked geographic concentration: almost half the students were located in the South East of England, and over a quarter in Greater London. The authors conclude that students are not driven to enrol in correspondence courses because of a lack of an alternative, but choose correspondence education because of the flexibility it offers: flexibility in terms of working at a pace and to a study plan dictated by the student: 72 and 70 per cent of students attached some importance to these two reasons respectively. Fifty per cent of students thought it promised greater economies of time. A large minority -45 per cent - of students thought the opportunity to engage in concentrated studies at various times during the year important. The non-availability of more direct education was also cited, but only by a minority of students -39 per cent - as was a preference for working alone -38 per cent. Only 16 per cent expressed any intention of combining correspondence study with other more direct forms of instruction.

The reasons for taking the particular course of study identified as the most important were principally associated with career advancement; this was true of both the students on professional courses, and those on the degree courses. The A-level students were largely preparing for higher education, although they also tended to cite intrinsic interest in the subjects.

\section{Student outcomes: course completion and drop-outs}

The outcomes for students using correspondence were taken using a retrospective survey: it indicated that 27 per cent (554) had completed the course; 43 per cent (907) were still engaged with their studies; 13 per cent (278) had interrupted them; and 15 per cent (316) had discontinued them. Glatter et al., ${ }^{49}$ claim the cited figure for the dropout rate is likely to be a gross underestimate- with course interruption often being a precursor of dropping out, if not a euphemism. Dropouts were most likely to occur during the first year of enrolment. The difficulties of successfully combining study with other demands on the students' time,

\footnotetext{
${ }^{46}$ Young and Farrell, 'Who Uses Correspondence Colleges?'

${ }^{47}$ Millerson, The Qualifying Associations.

${ }^{48}$ Glatter et al., Study by Correspondence; An Enquiry Into Correspondence Study for Examinations for Degrees and Other Advanced Qualifications.

${ }^{49}$ Glatter et al.
} 
principally their current employment, were cited as the source of the higher dropout rate, rather than deficiencies associated with the teaching method. Ultimately, those that actually took the final set of exams demonstrated a pass rate comparable to students from full-time courses.

A longitudinal extension of the 1967 survey was conducted in 1971 involving a randomly selected quarter of the original sample. The initial statement or identification of motivation for study showed no relation to a successful outcome. It was only the reconsidered motives that demonstrated any consistency: slightly over 50 per cent cited 'the qualification leads to higher study'; 48 per cent of the students who successfully completed their courses cited 'enjoyment of the subject'; and 32 per cent cited 'interest in the subject'; and following these are 'importance of being educated to a high standard' (31 per cent), and 'better use of leisure' (23 per cent).

There was apparently little relation between having previously obtained a higher education qualification and successful course completion: of those that completed their course by 1970, 33.9 per cent previously held a higher educational qualification; for those continuing the figure was 37 per cent; for those that had discontinued, 32.7 per cent. $^{50}$

The most frequently cited reason for abandoning the course was the difficulty of combining work and study, which was also a frequently cited reason for dropping-out amongst part-time students. Most of the dropouts -44 per cent - occurred within the first year of the course, and around 22 per cent in the second.

The most frequently cited reasons for opting to study by correspondence in 1971 included re-statements of those given in 1967 - the opportunity to work at a pace dictated by the student; the non-availably of more direct education; and included a newly cited reason - the opportunity to begin a course of study at any point in the year. The prevalence of other reasons frequently cited in 1967, such as (expected) economies of time, had however diminished.

\section{The experience of studying by correspondence}

The attitudes students expressed concerning their experiences of their own correspondence courses were largely positive: the institutions were regarded as efficiently run and exercises promptly returned. The course materials were also rated highly, in terms of their capacity to explain basic concepts, to test new knowledge, and to stress important points with clarity. The most substantial area of complaint was the tutors - specifically their lack of personal interest in the student, and their lack of help when students began falling behind. Harris ${ }^{51}$ points out that the tutor relationship is often a weak link in the correspondence method.

These attitudes can be contrasted with the type of student complaints identified by the Chairman of Wolsey Hall, Oxford. ${ }^{52}$ Along with issues ostensibly outside the colleges' control, such as the non-arrival of course material and non-supply of text books - the former blamed on postal delays, ${ }^{53}$ the latter on deficient publishers' stock - tutors were also

\footnotetext{
50 W. J. A. Harris, Home Study Students (Manchester: University of Manchester, Department of Adult Education, 1972).

51 W. J. A. Harris, 'Home Study for Examination: A Longitudinal Enquiry', The Vocational Aspect of Education 25, no. 62 (1 December 1973): 139-44, https://doi.org/10.1080/10408347308000211.

${ }^{52}$ Robert Gunning, Regulations and Legislation Regarding Correspondence Education: A Survey of Five Countries with Recommended Guidelines (UNESCO, ICCE, 1978).

${ }^{53}$ Richard Freeman, 'The National Extension College', in Education for Adults: Educational

Opportunities for Adults, ed. Malcolm Tight, vol. 2 (London: Croom Helm, in association with the Open
} 
identified as a substantial area of complaint. The complaints about the tutors tended to centre on a lack of advice, or on the tutors themselves being in some way 'irritating'; other areas of complaint included administrative errors, and study contracts - students' expectations of a refund if they dropped out, an issue which became subject to regulation by the Consumer Credit Act, 1975.

The consumer affairs publication Which $?^{54}$ conducted a review of 157 members' (subscribers) experiences of correspondence courses, and had two specialists review courses in O-level English, and Law (LLB degree). All the schools were accredited, and the students were largely positive about their experiences. The criticisms were, however, far more pointed than those identified above, highlighting problems symptomatic of correspondence education, even under conditions of accreditation. These concentrated on the course materials, which were found to be variously: out of date; containing large amounts of irrelevant material; or too heavily slanted towards a particular exam board's syllabus. The students also complained about the tutors, particularly in terms of the lack of the depth and quality of the feedback, as well as protracted turnaround times - the average was 12 days, but could stretch to three weeks, or more. These points, with the exception of the last, were also made by the specialists.

An earlier survey conducted by Which? ${ }^{55}$ before the accreditation of correspondence schools, identified similar complaints, but also a particular emphasis on inadequately produced course materials. The Which? 1963 survey also identified at least one incidence of possible fraud; nothing like this was reported in the 1977 review, which may indicate the positive impact of accreditation.

\section{Student experience of public and private providers}

A 1981 survey of 4,500 adults - more specifically mature students - participating in education included 1,292 engaged in correspondence education: in this research, education included both further and higher levels. Woodley ${ }^{56}$ and Woodley et al., ${ }^{57}$ used the data to compare the student populations in public and private correspondence institutions: the Open University undergraduate $(n=386)^{58}$ and associate students (329), the National Extension College (410), the National Association of Local Government Officers (NALGO) correspondence institute (130), and two large private correspondence colleges (297).

The results indicated pronounced heterogeneity both within and between the institutions' student populations although they were all being taught, ostensibly at least, by the same method, and through institutions performing the same function.

The private providers tended to be populated by vocationally orientated students enrolled in sub-degree courses: 69 per cent cited vocation as their motivation for studying, and 56 per cent were studying at A- or O-level (or an equivalent level). Furthermore, there was a distinct cast to the type of subject being studied: 55 per cent of enrolments were in social science subjects, and only 20 per cent in science courses, the remainder in arts courses. Students at private providers, and the NEC, were both characterised by low levels of

University, 1983), 188-202. Not entirely an exercise in shifting the blame, there was, for example, a two month postal strike in the UK in 1971.

${ }^{54}$ Which?, 'Correspondence Courses', Which?, no. August (1977): 465-67.

55 Which? 'Correspondence Courses', Which?, no. October (1963): 305-12.

${ }^{56}$ Alan Woodley, 'Distance Students in the United Kingdom', Open Learning, June 1986, http://eric.ed.gov/?id=ED306940.

${ }^{57}$ Alan Woodley et al., Choosing to Learn: Adults in Education (Milton Keynes: Open University Press, 1987).

${ }^{58}$ Woodley et al., A best guess, the number in the available copy is effectively illegible. 
academic attainment: about 70 per cent from both types of provider left school with O-levels or less; and both displayed low social mobility, the qualifications they left school with tending to be the qualifications they enrolled with.

The distinction between students at private providers and those at the NEC lay in their motivation for studying, and type of subject studied. Twice as many students at the NEC were studying Arts subjects, and half as many cited vocation as their motivation for studying.

There were, however, some measures that proved uniform across provider: employment status, the great majority of students being in some form of paid work; and father's social class, approximately 40 per cent of students having working class fathers, and one third 'service class', irrespective of their provider. All the student populations were older than the typical undergraduate, a likely product of the survey design, although they tended to be younger in the private providers (66 per cent aged 21-30 years old), somewhat older at the NEC (64 per cent 31 years or older) and oldest at the Open University (76 per cent 31 years or older).

\section{Correspondence tutors}

Harris ${ }^{59}$ estimated that there were a minimum of six to seven thousand tutors, and possibly considerably more across all subjects and levels in Britain, in 1973.

Harris ${ }^{60}$ surveyed approximately 569 tutors from seven colleges, employing about 1000 tutors in total. All seven colleges were accredited. The subjects taught by tutors in the survey covered banking, accountancy, secretarial, local government, and law, along with various A' levels and degree subjects. The sample, if it is considered representative, offers a profile of the composition of the teaching body in correspondence schools in the mid-1970s. Harris also surveyed nine colleges, employing around 1,750 part-time tutors.

\section{Characteristics of correspondence tutors}

The findings indicated correspondence school tutors were overwhelmingly male (73 per cent), heavily concentrated in the age range 30 to 60 years old (69 per cent, only 15 per cent were under the age of thirty, 16 per cent were aged 60 or over), and almost entirely part-time (99 per cent). The tutors', like the students', relation with the school was frequently at a distance.

Harris ${ }^{61}$ noted there had been a long-standing concern that correspondence tutors were under-qualified. The survey went some way to dispelling this suspicion: 96 per cent of the sample had either a degree or other 'relevant qualifications', a figure which rose to 99 per cent for degree course tutors. There was also a lower, but still significant proportion of tutors with teaching experience.

The numbers of students tutors were charged with ranged from less than ten up to 200 . In terms of their teaching practices, most tutors taught using model answers prepared either by their college (54 per cent) or by themselves ( 12 per cent): the remainder used no standard answer. The reasons for abandoning the model answers included deeming them irrelevant, or that those supplied were judged inadequate. A third of tutors had written to five students or less, in the previous two weeks. A tenth had written to thirty or more in the same period. Seventeen per cent wrote, on average, 20 words or less per student, 43 per cent twenty to fifty words, and 37 per cent wrote over 50 words per student. This varies by subject, possibly

\footnotetext{
${ }^{59}$ Harris, The Distance Tutor. Education by Correspondence.

60 Harris.

${ }^{61}$ Harris.
} 
reflecting the differing requirements of each subject: 25 per cent of accountancy tutors wrote 20 word or less, but only 11 per cent of secretarial tutors did so.

Attitudes to various aspects of teaching vary: commendation, clarity in responses, and a swift turn around are clearly considered important - in each case over 90 per cent of tutors expressed agreement concerning their importance- less so, brevity in responses (21 per cent agreed) and attention to students likely to drop out (27 per cent). The low priority associated with the latter attitude is convergent with one of the criticisms made by students, that they receive insufficient attention when falling or at risk of falling behind. It is possible that the tutors were simply accustomed to a high level of wastage, and did little to arrest it.

\section{Employment conditions and attitudes of correspondence tutors}

That many tutors were found to limit their teaching to simple correction and marking may have been related to the rates of remuneration associated with corresponded tutoring. As Harris ${ }^{62}$ points out there existed no wage-scale or a professional status for full-time tutors that could be used as a point of reference. Consequently, correspondence school tutors were financially unmoored, free only to accept or reject the contract they were offered by the college. The remuneration for part-time tutoring was found to be modest: $15 p-38 p$ per script and $£ 1.50$ per essay.

The low remuneration was perhaps off-set, but also made possible, by the kind of motivation to engage in correspondence teaching expressed by the respondents. Only 16 per cent identified economic motivations. Thirty-one per cent stated they were motivated by an interest in correspondence education as a particular form of teaching; 18 per cent that they were currently, at least, unable to teach in any other way - these were often former classroom teachers and current 'housewives'; and ten percent cited altruistic motives - to help students. The turnover of staff seemed low: in the college survey only ten per cent of all tutors had been employed for under three years.

There were few general training facilities available for new correspondence tutors either in this country or in most other countries, but the respondents were clear in their demand for further teacher training or instruction. The single most important form was tutor meetings (48 per cent), reflecting both their lack of contact with their peers, and their experience as tutors, as the next most popular form of instruction - manuals - received half this. However, a fifth of respondents didn't think correspondence teaching demanded any skills in addition to those of classroom teaching.

\section{The regulation of correspondence education}

Despite the prevalence of correspondence education, no single piece of legislation was created to govern the sector. The 1962 Correspondence Course (Registration) Bill was tabled but defeated. ${ }^{63}$ A proposed 1977 EEC (now EU) draft Directive proposing all correspondence schools should be accredited was, likewise, never enacted. Consequently, the sector remained subject to standard commercial law concerning profit-making commercial enterprises, relevant elements of which included The Sale of Goods Act, 1893/amended 1973; Companies Act, 1948/1967, where the organisation had been incorporated under English law, and the Company Law Consumer Credit Act,1974. The activities of correspondence schools, particularly in terms of recruitment of students, were also subject to the auspices of the Advertising Standards Authority (ASA), since its

\footnotetext{
62 Harris.

${ }^{63}$ Harris, 'Education by Post (England)'.
} 
establishment in 1975. The period 1975-1977 saw only eight cases of correspondence school's advertising referred to the ASA, of which four were up-held. ${ }^{64}$

Correspondence education was also subject to regulation by non-legal bodies. The Association of British Correspondence Colleges (ABCC), founded 1955, developed from an informal committee that coalesced after World War II in response to government approaches concerning tuition for the armed forces. The stated aims of the ABCC, which endures to this day, are: 'to safeguard the interests of students learning at home by ensuring high standards, and to provide services and a forum for discussion among its members'. ${ }^{65}$ ABCC essentially operates through an established a code of ethics, expressed in the foregoing quotation, to which the member organisations adhere. ${ }^{66}$ Gunning, however, dismissed the normative role of the $A B C C$ describing it as 'little more than a trade association concerned with protecting and promoting the interests of the member colleges'. ${ }^{67}$ There were 13 members in 1962/63, only a fraction of all correspondence colleges - Young and Farrell ${ }^{68}$ identified a further 37 .

The Correspondence College Standards Association was founded in 1963, its aim being 'the independent assessment of the academic quality and fitness for the declared purpose of any course submitted to it'. ${ }^{69}$ The statement is quoted from an advert in the New Scientist recruiting assessors; other than this the Correspondence College Standards Association seems to have left no trace. It does, however, appear, in its intent at least, a pale forerunner of the Council for the Accreditation of Correspondence Colleges (CACC), aiming to introduce an element of standardisation in the field of correspondence education, although at the level of the institution rather than course. The need for some form of validation perhaps became more acute throughout the late 1960s with the impending establishment of the Open University.

The CACC was established in 1969 following recommendations made in the report by the Committee on Accreditation of Correspondence Colleges chaired by Dr. C. E. Gurr formerly Chief Education Officer for Middlesex County Council.

The Gurr committee was funded and established by the Association of British Correspondence Colleges and the second largest group of colleges, the Cleaver-Hume group, combined these organisations accounted for 80 per cent of the market. ${ }^{70}$

The Gurr committee was formed as a response to the colleges' continued ineligibility for oversight by H.M. Inspectors. This ineligibility was a consequence of correspondence schools being neither administered by Local Authorities, nor being full-time educational establishments. Consequently, they were denied the opportunity to promote themselves as being officially 'recognised as efficient' in the manner of independent schools and colleges. ${ }^{71}$

The Gurr committee considered three possible courses of action: an Act giving the Department of Education and Science (DES) powers to inspect and licence colleges; selfregulation by a wider association of colleges; and a national approach realised through the

\footnotetext{
${ }^{64}$ Gunning, Regulations and Legislation Regarding Correspondence Education.

65 'ABCC', Promotional, ABCC- for the best providers of distance learning courses', 2016, http://www.homestudy.org.uk/.

${ }^{66}$ Gunning, Regulations and Legislation Regarding Correspondence Education.

${ }^{67}$ Gunning, 24.

68 Young and Farrell, 'Who Uses Correspondence Colleges?'

${ }^{69}$ Harry Trewman F., 'New Scientist', 20 February 1964.

${ }^{70}$ Morrish, Education Since 1800.

${ }^{71}$ Robert Presswood E., 'Accreditation - Britain's Contribution to Correspondence Tuition', Education \& Training 16, no. 8 (1974): 181-83.
} 
formation of a Council for Accreditation with an element of state representation. ${ }^{72}$ The committee recommended the third option, the establishment of a Council for the Accreditation of Correspondence Colleges (CACC) ${ }^{73}$ and set down recommendations for its constitution, organisation and financial structure. Hitherto, there had been no official state responsibility, or even oversight of the correspondence sector until the establishment of the CACC in 1969, and even then official involvement was minimal.

The role the state played extended no further than nominating the chairman and five members of the Council, along with two HMI assessors, representing the DES. Additionally, the Council featured five members representing the correspondence colleges. Its initial funding was a grant of $£ 10,000$ from the $A B C C$ and the Cleaver Hume group, to cover the Council's first two years. Subsequently, CACC was to be funded from registration and affiliation fees paid by accredited colleges.

The financial foundation and composition of the CACC was essentially the product of the two largest groups of correspondence colleges. A 1975 article in the Financial Times highlighted the difficulty this posed to the Councils' supposed independence, and the broader issues of combining profit with educational provision and the interests of the student. ${ }^{74}$ The CACC never-the-less provided the only protection of students' interests beyond those available in standard commercial law. Latterly the council became recognised as an education charity, and, from 1976, received grant aid from the DES, although the bulk of its funding was still derived from accredited colleges' subscriptions. ${ }^{75}$

There were an estimated ninety correspondence colleges in Britain in $1971,{ }^{76}$ twenty four having been awarded accreditation by 1971 , from an initial thirty applications. The number accredited by 1979 stood at 36 , and at 37 by $1981 .^{77}$ The increase was not achieved by steady accretion, but, rather, through a degree of churn. All colleges were asked to make annual returns, informing the council of any significant material changes in their management, courses, tuition etc. which might have a bearing on their accreditation status. The accreditation could be revoked, or withdrawn, by a vote of no less than eight of the 11 members. ${ }^{78}$

The Council's aims, amended in 1974, were 'to promote education and in particular to raise standards of tuition, education or training carried out wholly or partly by post'. ${ }^{79}$

\footnotetext{
${ }^{72}$ Kevin Smith C., 'Teaching at a Distance: A Comparative Study of Correspondence Education in Britain, Western Europe and Australia with Special Reference to External Studies at the University Level' (Associateship, University of London: Institute of Education, 1971).

${ }^{73}$ The CACC became the Open and Distance Learning Quality Council in 1995: Open \& Distance Learning Quality Council, 'The Open \& Distance Learning Quality Council', 2016, http://odlqc.org.uk/open-distance-learning-quality-council.

${ }^{74}$ Christopher Dunn, 'Learning by Post Lives On', The Financial Times, 13 January 1975, Slavery and Anti-Slavery.

${ }^{75}$ Jack Brosgall, 'Accreditation of Correspondence Colleges a Contribution to Correspondence Education', Distance Education 3, no. 2 (January 1982): 279-82, https://doi.org/10.1080/0158791820030208.

${ }^{76}$ Smith, 'Teaching at a Distance: A Comparative Study of Correspondence Education in Britain, Western Europe and Australia with Special Reference to External Studies at the University Level'. 77 Brosgall, 'Accreditation of Correspondence Colleges a Contribution to Correspondence Education'; Robert E. Pressman, 'Accreditation - Britain's Contribution to Correspondence Tuition', Education \& Training, 1974.

${ }^{78}$ Gunning, Regulations and Legislation Regarding Correspondence Education.

${ }^{79}$ Brosgall, 'Accreditation of Correspondence Colleges a Contribution to Correspondence Education', 280.
} 
Gunning ${ }^{80}$ surveying five countries' legislation and regulation of correspondence education concluded that the CACC was influential in maintaining ethical standards amongst accredited colleges, largely due to the involvement of the DES in the appointment of Council members. However, Gunning recognised it had no power over unaccredited institutions. Additionally, the DES (or Department for Education, by that stage) ceased to be associated with the CACC, the organisation becoming fully independent. The council now has a total of only five members, although this does include representation from the Open University.

\section{From correspondence to distance education}

British correspondence education was largely proprietorial, yet broadening its technological base was driven by educational interests rather than market imperatives.

The National Extension College (NEC), established by Michael Young in 1963, as a not-forprofit private college, was directed at adults and founded on the principles of distance learning, innovatively combining TV and radio broadcasts and recordings, course materials, correspondence and face-to-face tuition designed to address the problems of distance learning. Smith describes the institution as, 'not so much a correspondence college as a "multi-media" college'. ${ }^{81}$ It effectively acted as a pilot for the soon-to-be established University of the Air, or the Open University, as it became. ${ }^{82}$ Whatever the merits of other correspondence schools, the NEC had a rigorous pedagogic foundation.

By 1971 the NEC had over 1,000 students studying for London University degrees: total enrolments stood at 5,748 in 1972; 10,433 in 1975; but fell to 7,869 in 1976. The NEC was to reposition itself within the educational system with its development of FlexiStudy, producing course materials for distance adult education but working through local authorities and colleges. Its enrolments dwindled as the priority became the production of educational texts and other resources. Latterly there was a re-focus on education provision, and, by 1999, the NEC was dealing with around 10,000 enrolments annually.

Innovations in correspondence education associated with the NEC during the 1960s were paralleled, to some extent, by those that took place in the public sector - involving the Open University, local authorities, further education (FE) colleges - and, in some cases, private correspondence colleges. Rapid Results College began retailing their course materials to FE colleges who then provided the course work and teaching staff, although the course work was marked by Rapid Results. The National and Local Government Officers Association (NALGO) also developed a similar arraignment with FE colleges for students studying for local government examinations using NALGO's correspondence courses.

The publicly funded South West London Further Education College, adopted an approach termed 'directed private study', combining direct and postal tuition with continuous tutorial advice, developed entirely by the college itself. ${ }^{83}$ The college concentrated on commercial subjects, offering directed private study in accountancy, business studies for serving officers, and English, maths, and economics for Port Authority employees.

These innovations came as commercial correspondence education was entering a period of irreversible decline. That the most recent UK research was conducted in 1981 indicates something of the eventual fate of correspondence education; a headline from the Financial

${ }^{80}$ Gunning, Regulations and Legislation Regarding Correspondence Education.

${ }^{81}$ Smith, 'Teaching at a Distance: A Comparative Study of Correspondence Education in Britain, Western Europe and Australia with Special Reference to External Studies at the University Level', 36.

${ }^{2}$ NEC, 'About NEC', 2016, https://www.nec.ac.uk/content/about-nec.

${ }^{83}$ Smith, 'Teaching at a Distance: A Comparative Study of Correspondence Education in Britain, Western Europe and Australia with Special Reference to External Studies at the University Level'. 
Times in 1975 already expressed some surprise that that the form still existed: 'Learning by post lives on'. ${ }^{84}$

Changes in post-war society created particular problems for correspondence schools. The reservoir of potential students was drained as access to public higher and further education was expanded during the post-war years. Twenty new universities were founded throughout the 1960s; by the mid-1970s over 30 polytechnics - and 15 Central institutions in Scotland had also been established: in the early 1960s higher education institutions had 400,000 (full and part-time) students, by the year 2000 the figure was over two million. ${ }^{85}$

Demand was further eroded by the establishment of the Open University offering correspondence based degree courses that incorporated technological innovations few commercial schools seemed interested in or capable of emulating.

Further reductions in potential student numbers were realised as professional societies shifted their emphasis, often in response to the demands of potential members, from postal to face-to-face tuition; this was particularly telling in chartered accountancy, a longestablished and significant presence in correspondence education. In addition to the private tutorial schools founded through the 1960s and 1970, by 1979 there were 32 universities and 30 polytechnics offering degrees which could exempt students from the accountancy foundation examinations. ${ }^{86}$

In the face of these changes many of the early schools vanished, elements of them absorbed by more financially robust institutions. The UCC was incorporated by NEC; Foulks Lynch's publishing arm was acquired by Kaplan Financial - part of Kaplan Inc. in 2003. Others, like Bennett's, following name changes, faded into oblivion.

Furthermore, the pedagogic form correspondence education took was decidedly teacher centred. ${ }^{87}$ Given correspondence education's inherent restrictions, with its fixed transmission-based delivery it faced greater difficulties in adapting to a more student centred learning experience that might involve increased student choice or power. ${ }^{88}$ Consequently, correspondence education became characterised as technologically obsolete and educationally outmoded and inflexible, even if student-centred learning has not been as widespread as is often claimed. ${ }^{89}$

Correspondence education, now referred to as distance learning, still exists, although the medium itself has been utterly transformed from physical to digital.

\footnotetext{
${ }^{84}$ Dunn, 'Learning by Post Lives On'.

${ }^{85}$ David Greenaway and Michelle Haynes, 'Funding Higher Education in the UK: The Role of Fees and Loans*', The Economic Journal 113, no. 485 (1 February 2003): F150-66, https://doi.org/10.1111/1468-0297.00102.

${ }^{86}$ Geddes, 'The Development of Accountancy Education, Training and Research in England: A Study of the Relationship between Professional Education and Training, Academic Education and Research and Professional Practice in English Chartered Accountancy'.

${ }^{87}$ Susan J. Lea, David Stephenson, and Juliette Troy, 'Higher Education Students' Attitudes to Student-Centred Learning: Beyond 'Educational Bulimia"?', Studies in Higher Education 28, no. 3 (2003): 321-334; Maryellen Weimer, Learner-Centered Teaching: Five Key Changes to Practice (John Wiley \& Sons, 2002).

${ }^{88}$ Geraldine O'Neill and Tim McMahon, 'Student-Centred Learning: What Does It Mean for Students and Lecturers', 2005.

${ }^{89}$ John B. Biggs, Teaching for Quality Learning at University: What the Student Does (Buckingham: Open University Press, 1999); lan Farrington, 'Student-Centred Learning: Rhetoric and Reality?', Journal of Further and Higher Education 15, no. 3 (1991): 16-21.
} 
Massive Open Online Courses (MOOCS) represent a further innovation in distance learning, occupying territory once the preserve of correspondence schools. MOOCS feature digitised materials and, where it exists, a largely automated mode of marking / feedback, which, of course, are free to the student. The 'free' element of MOOCs, present at their inception, is unlikely to be sustained, but courses composed and delivered in this way are particularly suited to professional education, ${ }^{90}$ historically, a speciality for correspondence colleges.

Rapid Results, now RRC International, and Wolsey Hall both survived beyond the age of learning by post. The Open and Distance Learning Quality Council (ODLQC) has $15^{91}$ member colleges; the Association of British Correspondence Colleges (ABCC) has 35. ${ }^{92}$ Present day commercial providers of distance learning tend to be small scale and often highly specialised. The combined effect of the various changes influencing correspondence education means that large scale provision of any kind of advanced education is no longer the concern of commercial correspondence schools.

\section{Conclusion}

Correspondence education shares several features with contemporary distance learning, and its history is instructive about this mode of education in several respects.

Correspondence education allowed those unable or unwilling to take part in full or part time face-to-face tuition access to higher and profession education, effectively widening participation. Although students were generally charged it was by far the most economical alternative. It also had the general appeal of a flexible learning medium, in which the student was able to both set their own pace, and study around working hours. These are precisely the positive characteristics identified in contemporary online distance learning. ${ }^{93}$

Correspondence tuition was, though, often regarded as a second-rate form of education, a debate that now centres on distance learning. Concerns have been expressed that higher education by distance learning will amount to a second, and second rate, tier of education producing 'economy' degrees for the disadvantaged, with face-to-face tuition and 'luxury' degrees the preserve of the more advantaged. ${ }^{94}$

The history of correspondence education also has another lesson of contemporary relevance. Other than taking advantage of its founding technology, and the opportunity to retail higher and professional education, the for-profit providers that comprised much of the correspondence education sector showed little or no technological innovation in the delivery of tuition. When innovations arrived, such as recorded lessons, or t.v. broadcasts it was either via the not-for-profit or public sectors. Proponents of for-profit education often trail its advantages including increased propensity for innovation; yet the case of correspondence education is an example of a sector of higher education provision largely run for-profit but failing to engage in any significant innovation after its initial establishment. The history of corresponded education indicates that the presence of for-profit institutions competing amongst themselves is not sufficient to guarantee increased efficiency and innovation, and

${ }^{90}$ Diana Laurillard and Eileen Kennedy, 'Investigating the Transformative Potential of MOOCs for Professional Development on the Large Scale', CGHE Events, 5 July 2018,

http://www.researchcghe.org/events/2018-07-05-investigating-the-transformative-potential-of-moocsfor-professional-development-on-the-large-scale/.

${ }^{91}$ ODLQC, 'Accredited Providers', 2017, https://www.odlqc.org.uk/accredited-providers.

92 'ABCC'.

${ }^{93}$ Diana Laurillard and Eileen Kennedy, 'The Potential of MOOCs for Learning at Scale in the Global South', Centre for Global Higher Education, Working Paper Series, Lancaster, UK 42 (2017): 4.

${ }^{94}$ Scott Carlson and Goldie Blumenstyk, 'For Whom Is College Being Reinvented?', The Chronicle of Higher Education, 17 December 2012, https://www.chronicle.com/article/The-False-Promise-ofthe/136305. 
the failure to adapt and incorporate technical innovation led to the almost total extinction of an entire species of higher education provider. 


\section{Acknowledgements}

l'd like to acknowledge the contributions made by Professor Gareth Parry and Professor Vikki Boliver, along with the two anonymous reviewers whose suggestions led to improvements in the paper.

\section{Disclosure statement}

No potential conflict of interest was reported by the author.

\section{Funding}

The research for this paper was undertaken with the support of the Economic and Social Research Council (UK), the Office for Students (UK) and Research England (UK) (grant reference ES/M010082/1).

\section{Notes on contributor}

Stephen Hunt is Research Associate in the Centre for Global Higher Education at UCL Institute of Education concentrating on alternative providers of higher education. Stephen studied for a PhD in psychology at UCL, and has worked in educational research, on projects such as Effective Pre-School, Primary and Secondary Education (EPPSE). Stephen has also conducted research in areas such as risk perception, trust and risk communication. 